\title{
Positive Psychology Course: A Way to Improve Well-Being
}

\begin{tabular}{ccc}
\hline Article Type & Received Date & Accepted Date \\
Research & 14.07 .2019 & 17.12 .2019 \\
\hline
\end{tabular}

\author{
Ayşe Berna Sarı Arasıl* \\ Fatma Turan ${ }^{* *}$ \\ Barış Metin ${ }^{* * *}$ \\ Hande Sinirlioğlu Ertaş ${ }^{* * * * *}$ Nevzat Tarhan ${ }^{* * * * * *}$
}

\begin{abstract}
Today many universities provide courses on positive psychology. Previous studies have showed that the positive psychology course may serve to improve well-being of students. However, previous studies had limitations in sample size and sample characteristics. In the current study, we aimed to assess the beneficial effect of a compulsory positive psychology course on well-being, happiness, emotional expressiveness, life satisfaction, emotional intelligence and social intelligence in addition to experiences in close relationships. In total 308 undergraduate students (Mean age $=20, \mathrm{SD}=3 ; 237$ female, 71 male) who took the positive psychology course volunteered to participate and filled in self-report questionnaires before and after the course (14 weeks later). The results showed that the participants' overall happiness and emotional expressiveness increased after taking the positive psychology course. We conclude that positive psychology course is not only instructive, but it may also serve to increase happiness and emotional abilities of students.
\end{abstract}

Keywords: Positive psychology, positive psychology course, well-being, happiness.

\footnotetext{
* Assist. Prof., Dr., Yeditepe University, Faculty of Arts and Sciences, Department of Psychology, İstanbul, Turkey. E-mail: abernasari@gmail.com, https://orcid.org/0000-0001-6870-4758.

** Faculty Member, Vocational School of Health Services, Electroneurophysiology Program, Uskudar University, İstanbul, Turkey. E-mail: fatma.turan@uskudar.edu.tr, https://orcid.org/0000-0002-9982-4792.

${ }^{* * *}$ Assoc. Prof. Dr., MD, School of Humanities and Social Sciences, Department of Psychology, Uskudar University, İstanbul, Turkey. E-mail: baris.metin@uskudar.edu.tr https://orcid.org/0000-0003-1626-058X.

**** Faculty Member, School of Humanities and Social Sciences, Department of Psychology, Uskudar University, İstanbul, Turkey. E-mail: hande.ertas@uskudar.edu.tr, https://orcid.org/0000-0003-2995-920X.

${ }^{* * * * * *}$ Prof. Dr., MD, Department of Psychology, Uskudar University, NPI İstanbul Neuropsychiatry Hospital, İstanbul, Turkey. E-mail: nevzat.tarhan@uskudar.edu.tr. https://orcid.org/ 0000-0002-6810-7096.
} 


\title{
Pozitif Psikoloji Dersi: İyi Oluşu Arttırmaya Yönelik Bir Yol
}

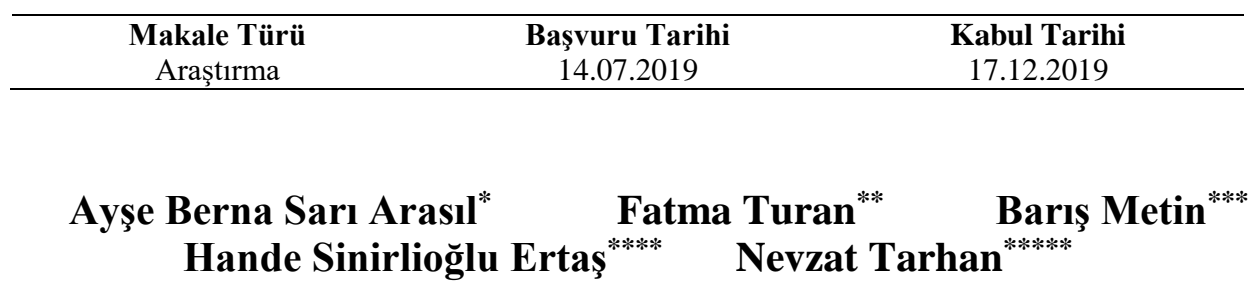

\begin{abstract}
$\ddot{O} \mathbf{z}$
Pozitif psikoloji akımı, güncel alanyazına önemli katkıları ile etkinliğini giderek arttırmaktadır. Pozitif psikolojinin etkinliği, farklı alanlara yansımaları ile yaygınlaşamaya devam etmektedir. Bugün birçok üniversitede pozitif psikoloji verilen dersler arasında yer almaktadır. İlgili alanyazın bulguları, Pozitif psikoloji dersinin öğrencilerin öznel iyi-oluş düzeylerini arttırabileceğini göstermektedir. Ancak, önceki çalışmalar incelendiğinde, katılımcı sayıları sayısı ve katılımcıların özellikleri bakımından kısıtlılıklar olduğu da görülmüştür. Bu çalışmada (zorunlu ders olan) Pozitif Psikoloji dersinin, yakın ilişkiler kurma, öznel iyi-oluş, mutluluk, duyguları ifade, yaşam doyumu, duygusal zeka ve sosyal zeka gibi farklı değişkenler üzerine faydalarının değerlendirilmesi amaçlanmıştır. Çalışmaya pozitif psikoloji dersini alan 308 üniversite lisans öğrencisi (Ortalama yaş $=20 ; 237$ kadın) gönüllü olarak katılmıştır. Çalışma grubunda yer alan öğrenciler, öz-bildirim tarzı değerlendirme anketlerini ilk ders öncesinde ve son dersin ardından (14 hafta sonra) yanıtlamışlardır. Verilerin analizinden elde edilen bulgular, öğrencilerin mutluluk düzeyi ve duygu ifadelerinde pozitif psikoloji dersleri sonunda artış olduğu yönündedir. Sonuç olarak araştırma bulguları; pozitif psikoloji içerikli bir dersin bilgilendirici eğitimin ötesinde; öğrencilerin duygularını daha iyi ifade etmelerini ve daha mutlu olmalarını sağlayan etkin bir eğitim içeriği olduğunu göstermiştir.
\end{abstract}

Anahtar Sözcükler: Pozitif psikoloji, pozitif psikoloji dersi, öznel iyi oluş, mutluluk.

\footnotetext{
*Dr. Öğr. Üyesi, Yeditepe Üniversitesi, Fen Edebiyat Fakültesi, Psikoloji Bölümü, İstanbul, Türkiye. E-posta: abernasari@gmail.com, https://orcid.org/0000-0001-6870-4758

** Ögretim Görevlisi, Sağlık Hizmetleri Meslek Yüksek Okulu, Elektronörofizyoloji Programı, Üsküdar Üniversitesi, İstanbul, Türkiye. E-posta: fatma.turan@uskudar.edu.tr, https://orcid.org/0000-0002-9982-4792.

*** Doç. Dr., İnsan ve Toplum Bilimleri Fakültesi, Psikoloji Bölümü, Üsküdar Üniversitesi, İstanbul, Türkiye. E-posta: baris.metin@uskudar.edu.tr https://orcid.org/0000-0003-1626-058X.

***** Ögretim Görevlisi, İnsan ve Toplum Bilimleri Fakültesi, Psikoloji Bölümü, Üsküdar Üniversitesi, İstanbul, Türkiye. E-posta: hande.ertas@uskudar.edu.tr, https://orcid.org/0000-0003-2995-920X.

${ }_{* * * * * *}^{*}$ Prof. Dr., Psikoloji Bölümü, Üsküdar Üniversitesi, NPİstanbul Nöropsikiyatri Hastanesi, İstanbul, Türkiye. E-posta: nevzat.tarhan@uskudar.edu.tr. https://orcid.org/0000-0002-6810-7096.
} 


\section{Introduction}

Positive psychology is a branch of psychology which emphasizes positive experiences and individual traits promoting subjective wellbeing and the quality of life while preventing pathologies derived from an unfruitful and meaningless life (Seligman \& Csikszentmihalyi, 2000). This emerging field of psychology received increased attention in the last decades (Seligman, Steen, Park, \& Peterson, 2005; Warren, Donaldson, \& Donaldson, 2017). Positive Psychology attracted the scientific interest as it showed a new perspective to look at human beings' mental health. The mental health practitioners and the scholars had been putting efforts on the descriptions and the ways to deal with mental illnesses. This new approach, contributed to field by shifting the perspective from 'abnormal' to 'strengths to stay normal' (Tarhan, 2016). Furthermost the scientific interest was to build up the thriving society to prevent pscyhopathologies. Accordingly, several universities offer positive psychology course in their curriculum and great number of students are interested in subscribing for positive psychology course (Russo-Netzer \& Ben-Shahar, 2011).

In line with the APA guidelines for Psychology Major (Halonen et al., 2007), positive psychology course does not only offer theoretical knowledge to the students, it also provides them with an opportunity for self-improvement. However, how positive psychology course contribute to the wellbeing of university students has been addressed only by few studies. In a study by Maybury (2012) students filled in self-report questionnaires of wellbeing before and after taking the positive psychology course. Results of the study showed that after taking the positive psychology course students reported improvements in several aspects of wellbeing including; mindfulness, selfactualization, hope and subjective happiness. Another study assessing the potential benefits of positive psychology course on students was conducted by Goodmon et al. (2016). In that study, authors compared students who took positive psychology course to the students who took social psychology course. Similar to the Maybury (2012) study, Goodmon et al. (2016) asked students to fill in selfreport questionnaires of wellbeing before and after the course. Their results showed that students who enrolled in the positive psychology course reported elevated life satisfaction, greater happiness, and lower scores in depression and perceived stress. Similar gains were not observed in the group of students who were enrolled in the social psychology course.

Previous studies provide us valuable evidence about the potential benefits of learning about positive psychology. However, these studies had important limitations worthy of discussing. Firstly, in the previous studies positive psychology course was offered as an elective course. Hence, the sample selection of these studies could be biased since the students who prefer enrolling in positive psychology course can be those who are already interested in the topics of positive psychology and willing to improve themselves. Secondly, both Maybury (2012) and Goodmon et al. (2016) reported that the sample size was small.

In this study, we built on the methodology, results and the limitations of previous studies to test the benefits of taking the positive psychology course on well-being and social-emotional abilities. For this purpose, bachelor students who took positive psychology course were invited to fill in self-report questionnaires in happiness, emotional intelligence, mental wellbeing, expressing emotions, life satisfaction, attachment and social intelligence before (beginning of the semester) and after the course (end of the semester). Participation in the study was voluntary, yet positive psychology course was a part of regular curriculum for all the students at the university where the participants were recruited. This approach allowed us to recruit a large number of participants who enroll in the positive psychology course with no specific interest in the positive psychology topics in advance. In this study, we expected that the students will report improvement in the self-report questionnaires mentioned above at the end of the course as compared to their previous scores.

\section{Method}

\section{Participants}

The participants consisted of 308 students of Uskudar University aged between 18 to 47 (Mean age $=20, \mathrm{SD}=3 ; 237$ female) in Academic year 2017-2018. Although taking the course was compulsory, participation in the study was completely on voluntary basis. Participants were students of the following undergraduate programs: Emergency and Disaster Management, Oral and Dental Health, Nutrition and Dietetics, Biomedical Equipment Technology, Child Development, Child Protective and Nursing Services, Dental Prosthesis Technology, Electroneurophysiology, 
Occupational Therapy, Food Technology, Nursing, First and Emergency Aid, Social Work. The study protocol was approved by the ethics committee.

\section{The Course Content}

Positive psychology and communication skills course are taught by psychologists (MsC) with expertise or training in the field of positive psychology. The course content consists of the following topics: Definition of positive psychology and basic concepts, Theoretical foundations of positive psychology, Introduction to social cognitive neuroscience, Behavior-brain relationship, Happiness science, Positive psychology applications, Emotional intelligence, Recognizing self and awareness, Recognizing others and empathy, Communication skills and relationship management, Motivation and planning, Problem solving skills, Healthy decision making, Resilience and agreeableness.

\section{Procedure}

The questionnaires were given to the participants during the first lecture of Positive Psychology course in the following order: Life Evaluation Question, Emotional Intelligence Rating Scale (Schutte et al.,1998; Ergin, 2000), Warwick-Edinburgh Mental Well-Being Scale (Tennant et al., 2007; Keldal, 2015), Oxford Happiness Questionnaire (Argyle, 1989; Dogan \& Sapmaz, 2012), Emotional Expressiveness Questionnaire (King and Emmons, 1990; Kuzucu, 2011), Satisfaction with Life Scale (Diener et al., 1985; Durak et al., 2010), Personal Wellbeing Index (Wellbeing, 2006; Meral, 2015), Experiences in Close Relationships Questionnaire (Fraley et al., 2000; Selçuk et al., 2005) and Tromso Social Intelligence Scale (Silvera et al., 2001; Doğan \& Çetin, 2009). At the end of the semester (14 weeks later), students filled in the above mentioned questionnaires once again. They were thanked for their contribution and provided a contact address for their further questions.

\section{Data Collection Tools}

\section{Life Evaluation Question}

Life quality question is a single question assessing the level of happiness via 5 point Likert type scale. (How do you rate yourself when you think about your whole life in general? (1) very unhappy (2) unhappy (3) moderately happy (4) pretty happy and (5) very happy.)

\section{Emotional Intelligence Rating Scale}

The Emotional Intelligence Rating Scale was designed to measure emotional intelligence based on Schutte et al., (1998). The validity and reliability study in Turkish was conducted by Ergin (2000; Cronbach alpha coefficient of the scale was 0.94). The scale consists of five sub-scales (social skills, empathy, being aware of their feelings, controlling their emotions, self-motivation), yet a total score of emotional intelligence can also be obtained. The test consists 30 Likert type items with the following response options: 1: Totally disagree, 2: Mostly disagree, 3: I some agree, 4: I agree, 5: Mostly agree, 6: Totally agree. In scale scores 129 and below indicate low, scores between 130-154 indicate normal and scores above 155 indicate high emotional intelligence (Ergin, 2000).

\section{Warwick-Edinburgh Mental Well-Being Scale}

Tennant et al. (2007) developed the Warwick-Edinburg Mental Well-Being Scale (WEMWS) and the validity and reliability study of the Turkish form was performed by Keldal (2015). WEMWS is a self-report style scale consisting of 14 items constructed to measure mental well-being. The scale focuses on both hedonic and eudaimonic dimensions of mental well-being (Keldal, 2015). The Cronbach Alpha coefficient of the scale was found .89.

\section{Oxford Happiness Questionnaire}

Oxford Happiness Questionnaire was developed by Hills and Argyle (2002) for measuring happiness. The validity and reliability study of the Turkish form was conducted by Dogan and Sapmaz (2012). According to the reliability analysis, Cronbach alpha internal consistency coefficient is 0.91 ; 
reliability coefficient assessed via test half-life method is 0.86 and composite reliability is 0.91 . This scale contains 6-Likert-type (1-never disagree, 6-fully agree) questions and includes 29 items. High scores on the scale indicate greater happiness.

\section{Emotional Expressiveness Questionnaire}

The Emotional Expressiveness Questionnaire was developed by King and Emmons (1990). The scale was adapted to Turkish by Kuzucu (2011). The Cronbach Alpha $(\alpha=.85)$ and test-retest values $(r=.85)$ were sufficient. The scale consists of 16 items assessing to what extent "positive", and "negative" emotions are expressed. It is a 7 point Likert type scale: (1) strongly disagree, (2) disagree, (3) not very disagree, (4) I'm undecided, (5) I agree a little, (6) I agree and (7) completely agree. Higher scores show the greater comfort while expressing emotions.

\section{Satisfaction with Life Scale}

Satisfaction with Life Scale was developed by Diener et al. (1985) and Turkish version was adapted by Durak et al., (2010). Originally reported internal consistency was .87 and the test-retest reliability was .82 . In the Turkish version, internal consistency coefficient was .81 and the corrected item total correlations range varied from .55 to .63 (Durak et al., 2010). It is a 5-item scale which mainly focuses on the global life satisfaction using a 7 point Likert-type items ((1) strongly agree to (7) strongly agree). The total scores of participants on the scale ranges from 5 to 35 . Greater scores in this scale indicate increased life satisfaction.

\section{Personal Wellbeing Index}

The Personal Well-Being Index-Adult (KIO-H) form is a thematic scale that aims to measure the subjective well-being. It was developed by International Wellbeing Group (2006, Turkish version; Meral, 2014). The internal consistency coefficient was reported as 0.81 . The scale primarily focuses on eight domains of wellbeing (standard of living, personal health, success in life, personal relationships, personal security, social trust/belonging, future trust and spirituality/religion). It consists of 8 Likert type items ((1) I am not satisfied at all, (5) I am undecided, (10) completely satisfied). The increase in the total score indicates the increase in the perception of personal well-being.

\section{Experiences in Close Relationships Questionnaire}

The Experiences in Close Relationships Questionnaire (Fralley, Heffernan, Vicary, \& Brumbaugh, 2000). The reliability and validity study of the Turkish version was conducted by Selçuk, Günaydın, Sümer and Uysal (2005). The test has a high level of internal consistency for avoidance and anxiety dimensions. The Cronbach Alpha coefficients for these dimensions are .90 and .86 respectively. The test-retest reliability is .82 for anxiety dimension and .81 for avoidance. The inventory has two dimensions: 36 items in anxiety and 18 items in avoidance. In the questionnaire, participants are asked to evaluate their feelings toward romantic relationships in a 7 point Likert-type (1-none, 4-undecided /no idea, 7-totally agree). High score from the scale indicates insecure attachment.

\section{Tromso Social Intelligence Scale}

The Tromso Social Intelligence Scale was developed by Silvera, Martinussen and Dahl (2001). The reliability and validity study of Turkish version was calculated by Doğan and Çetin (2009). Cronbach alpha was .83; test-retest relliabilty was .80 and split half reliability coefficients was reported as .75. On this scale, there are 21 Likert type questions (1-not suitable at all, 5-fully suitable). 


\section{Results}

Series of paired-sample t-tests were performed to assess pre to post course differences on the scores of the questionnaires stated in the method section (Table 1). For multiple comparisons, Benjamini-Hochberg correction was performed on the p-values. Our results revealed that participants showed increased scores in life evaluation question and Emotional Expressiveness Questionnaire after the course. Marginally significant pre-post increase was observed in Satisfaction with Life Scale ( $\mathrm{p}=$ .07). Pre to post differences were not observed in the Emotional Intelligence Reating Scale, WarwickEdinburgh Mental Wellbeing Scale, Oxford Happiness Questionnaire, and Personal Wellbeing Index. Lastly, there was a decline in the scores of Tromso Social Intelligence Scale and an increase in the scores of Experiences in Close Relationships Questionnaire which reflects an increment in attachment-related anxiety and avoidance.

\section{Table 1}

Paired T test results for pre-post course comparison of questionnaire scores.

\begin{tabular}{lllcl}
\hline Measurement Tool & $\begin{array}{l}\text { Pre-Course } \\
\boldsymbol{M}(\boldsymbol{S D})\end{array}$ & $\begin{array}{l}\text { Post-Course } \boldsymbol{M} \\
(\boldsymbol{S D})\end{array}$ & $\boldsymbol{t}$ value & $d f$ \\
\hline Life Evaluation Question & $3.05(0.61)$ & $3.26(0.61)$ & $5.24 * *$ & 257 \\
$\begin{array}{l}\text { Emotional Intelligence } \\
\text { Rating Scale }\end{array}$ & $4.11(0.66)$ & $4.12(0.73)$ & 0.12 & 307 \\
$\begin{array}{l}\text { Warwick-Edinburgh Mental } \\
\text { Wellbeing Scale }\end{array}$ & $3.80(0.68)$ & $3.78(0.70)$ & 0.49 & 307 \\
$\begin{array}{l}\text { Oxford Happiness } \\
\text { Questionnaire }\end{array}$ & $4.02(0.75)$ & $3.98(0.69)$ & 1.00 & 305 \\
$\begin{array}{l}\text { Emotional Expressiveness } \\
\text { Questionnaire }\end{array}$ & $4.71(0.73)$ & $4.80(0.73)$ & $2.32^{*}$ & 306 \\
$\begin{array}{l}\text { Satisfaction with Life Scale } \\
\text { Personal Wellbeing Index }\end{array}$ & $4.26(1.26)$ & $4.40(1.40)$ & 2.06 & 299 \\
$\begin{array}{l}\text { Experiences in Close } \\
\text { Relationships Questionnaire }\end{array}$ & $3.58(0.76)$ & $3.69(0.78)$ & 0.71 & 300 \\
$\begin{array}{l}\text { Tromso Social Intelligence } \\
\text { Scale }\end{array}$ & $3.59(0.52)$ & $3.44(0.53)$ & $2.63^{*}$ & 299 \\
\hline
\end{tabular}

\section{Discussion, Conclusion and Recommendations}

In this study, we aimed to assess the impact of taking the Positive Psychology course on wellbeing and social-emotional abilities of a large group of students. The results indicate that after the Positive Psychology course the participants rated themselves as happier in general. In addition, their level of emotional expressiveness increased significantly. A near significant increase in life satisfaction was also observed after the course. These results indicate that the course might have resulted in an increase in general happiness and emotional expression.

We observed several advantages of taking positive psychology course on happiness and emotional expressiveness, yet our results also showed a decline in participants' self-evaluation of their social intelligence and an increase in anxiety and avoidance for attachment development in close (romantic) relationships. Although the decrease in Tromso Social Intelligence scale appears to be paradoxical, it must also be acknowledged that this is a self-evaluation scale and is not an objective 
measure of social intelligence. One of the primary aims of positive psychology course was to provide knowledge on social skills and abilities. Hence, a decrease in social intelligence scores might have occurred due to an increased insight in development of such abilities. In other words, it can be argued that after taking the course students might have a greater knowledge to evaluate their social intelligence and became more critical of themselves. However, a further study should evaluate the change in social intelligence after the course using a relatively more objective measure.

Secondly, we observed an increase in the anxious and avoidant attachment style in romantic relationships, which was also an unexpected finding. The age for having the first serious relationship is typically during the first year of university (age of 18-19; Regan, Durvasula, Howell, Ureno, \& Rea, 2004) and majority of our participants $(\mathrm{N}=244)$ aged between 18 and 19 . Hence, many of our participants might be having their first serious romantic relationship while they were taking the positive psychology course. This might possibly have influenced their evaluation of attachment during a romantic relationship and while evaluating a real serious romantic relationship, they might possibly report greater anxiety as compared to a hypothetical one. Furthermore, attachment related issues in romantic relationship might appear for the first time during their first serious relationship. However, future studies need to assess the relationship status of course-takers before reaching to a firm conclusion about the association between taking positive psychology course and attachment styles in romantic relationships. In addition, although being in a serious relationship for the first time may increase anxiety and avoidance, it is possible that students of positive psychology course might have experienced a lesser degree of these adverse experiences. However, there was not a control group in this study for comparison. Because positive psychology course was a must course at Uskudar University, all students took the course and we did not have the chance to include a control group. Hence, future studies employing a control group is highly recommended, in order to better clarify positive psychology course related improvements.

Lastly, we could not observe any course-related improvements in self-report questionnaires assessing wellbeing. This finding is incompatible with the study of Maybury (2013) where improvement in wellbeing was observed. However, as mentioned earlier, in Maybury's study, positive psychology course was elective. Hence, participants might be the students who were already eager to improve themselves in wellbeing unlike the current study. In the current study, we could not find an improvement in emotional intelligence either. However, observing an improvement in such a trait measure might be too ambitious in fourteen weeks. Future studies are recommended to have follow-up assessments.

The main strength of the current study is the large sample size as compared to the previous studies. For instance, Maybury (2012) conducted a study with 23 undergraduate students and Goodmon et al. (2106) recruited 38 undergraduate students. In addition, in our case, the course was compulsory, and unlike previous studies any effect due to high motivation is thus minimized. However, we still cannot eliminate the expectancy effect, as students might believe that taking the course would increase their well-being. Despite of the limitations, our results suggest taking positive psychology course has a potential to increase students' wellbeing and help them to gain greater insight in their social-emotional abilities.

\section{References}

American Psychological Association. (2007). APA guidelines for the undergraduate psychology major.

Argyle M, Martin M, Crossland J. (1989). Happiness as a function of personality and social encounters: In Forgas JP, Innes JM. (editors). Recent Advances in Social Psychology: An International Perspective. North-Holland: Elsevier,189-203.

Bar-On, R. (2010). Emotional intelligence: an integral part of positive psychology. South African Journal of Psychology, 40(1), 54-62.

Chang, K. B. (2008). Can We Improve Emotional Intelligence? Addressing the Positive Psychology Goal of Enhancing Strengths-Chapter 2 from" Emotional Intelligence: Perspectives on Educational and Positive Psychology". 
Diener, E. D., Emmons, R. A., Larsen, R. J., \& Griffin, S. (1985). The satisfaction with life scale. Journal of personality assessment, 49(1), 71-75.

Doğan, T., \& Çetin, B. (2009). Tromso sosyal zekâ ölçeği Türkçe formunun faktör yapısı, geçerlik ve güvenirlik çalışması [The Validity, Reliability and Factorial Structure of the Turkish Version of the Tromso Social Intelligence Scale]. Educational Sciences: Theory and Practice, 7(1), 241268.

Doğan, T., \& Sapmaz, F. (2012). Oxford mutluluk ölçeği Türkçe formunun psikometrik özelliklerinin üniversite öğrencilerinde incelenmesi [Psychometric properties of Turkish version of Oxford Happiness Questionnaire in University Students]. Düşünen Adam Psikiyatri ve Nörolojik Bilimler Dergisi [Düşünen Adam Journal of Psychiatry and Neuroscience], 25(4), 297-304.

Durak, M., Senol-Durak, E., \& Gencoz, T. (2010). Psychometric properties of the satisfaction with life scale among Turkish university students, correctional officers, and elderly adults. Social Indicators Research, 99(3), 413-429.

Ergin, F. E. (2000). Üniversite öğrencilerinin sahip oldukları duygusal zeka düzeyi ile 16 kişilik özelliği arasında ilişki üzerine bir araştırma [A Research On the Relationship Between Personality Chracteristics and The Emotional Intelligence Level Of University Students] (Unpublished master's thesis). Selçuk University, Konya, Turkey.

Fraley, R. C., \& Shaver, P. R. (2000). Adult romantic attachment: Theoretical developments, emerging controversies, and unanswered questions. Review of General Psychology, 4, 132-154.

Fraley, R. C., Heffernan, M. E., Vicary, A. M., \& Brumbaugh, C. C. (2011). The experiences in close relationships-Relationship Structures Questionnaire: A method for assessing attachment orientations across relationships. Psychological assessment, 23(3), 615.

Goodmon, L. B., Middleditch, A. M., Childs, B., \& Pietrasiuk, S. E. (2016). Positive psychology course and its relationship to well-being, depression, and stress. Teaching of Psychology, 43(3), 232-237.

Halonen, J. S., Appleby, D. C., Brewer, C. L., Buskist, W., Gillem, A. R., Halpern, D., \& Whitlow, V. M. (2007). APA guidelines for the undergraduate psychology major. Washington, DC: American Psychological Association.

Hills, P., \& Argyle, M. (2002). The Oxford Happiness Questionnaire: a compact scale for the measurement of psychological well-being. Personality and individual differences, 33(7), 10731082.

International Wellbeing Group. (2006). Personal Wellbeing Index—Adult (PWI-A)

Keldal, G. (2015). Warwick-Edinburgh Mental İyi Oluş Ölçeği’nin Türkçe Formu: Geçerlik ve güvenirlik çalışması [The Validity and Reliability of the Turkish Version of the WarwickEdinburgh Mental Well-Being Scale]. The Journal of Happiness \& Well-Being, 3, 103-115.

King, L. A., \& Emmons, R. A. (1991). Psychological, physical, and interpersonal correlates of emotional expressiveness, conflict, and control. European Journal of Personality, 5(2), 131-150.

Kuzucu, Y. (2011). Duyguları İfade Etme Ölçeği'nin Uyarlanması: Geçerlik ve Güvenirlik Çalışmaları [Adaptation of Emotional Expression Questionnaire: Validity and Reliability]. Kastamonu Eğitim Dergisi [Kastamonu Education Journal], 779.

Maybury, K. K. (2013). The influence of a positive psychology course on student well-being. Teaching of Psychology, 40(1), 62-65.

Meral, B. F. (2014). Kişisel iyi oluş indeksi-yetişkin Türkçe formunun psikometrik özellikleri [Psychometric properties of Turkish form of the Personal Well-Being Index-Adult]. The Journal of Happiness and Well-Being, 2(2), 119-131.

Regan, P. C., Durvasula, R., Howell, L., Ureño, O., \& Rea, M. (2004). Gender, ethnicity, and the developmental timing of first sexual and romantic experiences. Social Behavior and Personality: An International Journal, 32(7), 667-676.

Russo-Netzer, P., \& Ben-Shahar, T. (2011). 'Learning from success': A close look at a popular positive psychology course. The Journal of Positive Psychology, 6(6), 468-476. 
Schutte, N. S., Malouff, J. M., Hall, L. E., Haggerty, D. J., Cooper, J. T., Golden, C. J., \& Dornheim, L. (1998). Development and validation of a measure of emotional intelligence. Personality and individual differences, 25(2), 167-177.

Selçuk, E., Günaydın, G., Sümer, N., \& Uysal, A. (2005). Yetişkin bağlanma boyutları için yeni bir ölçüm: Yakın ilişkilerde yaşantılar envanteri-II’nin Türk örnekleminde psikometrik açıdan değerlendirilmesi. [A new measure for adult attachment styles: The psychometric evaluation of Experiences in Close Relationships - Revised (ECR-R) on a Turkish sample]. Türk Psikoloji Yazılarl [Turkish Psychological Articles], 8(16), 1-11.

Seligman, M. E., \& Csikszentmihalyi, M. (2000). Positive psychology: An introduction (Vol. 55, No. 1, p. 5). American Psychological Association.

Seligman, M. E., Steen, T. A., Park, N., \& Peterson, C. (2005). Positive psychology progress: empirical validation of interventions. American psychologist, 60(5), 410.

Silvera, D., Martinussen, M., \& Dahl, T. I. (2001). The Tromsø Social Intelligence Scale, a self-report measure of social intelligence. Scandinavian journal of psychology, 42(4), 313-319.

Tarhan, N., Gümüşel, O., \& Sayım, A. (2013). Pozitif psikoloji: Çoklu zeka uygulamaları. [Positive Psychology: Multiple Intelligence Applications]. Timaş Publishing.

Tennant, R., Hiller, L., Fishwick, R., Platt, S., Joseph, S., Weich, S., ... \& Stewart-Brown, S. (2007). The Warwick-Edinburgh mental well-being scale (WEMWBS): development and UK validation. Health and Quality of life Outcomes, 5(1), 63.

Warren, M., Donaldson, S., \& Donaldson, S. (2017). Evaluating Scientific Progress in Positive Psychology. SI Warren, Meg A.; Donaldson (Ed.), Scientific Advances in Positive Psychology, 111. 
